\title{
Utilisation of Cover Crops: Implications for Conservation Agriculture Systems in a Mediterranean Climate Region of South Africa
}

\section{Ernst H. Smit}

Stellenbosch University

Johann A. Strauss

Stellenbosch University

Pieter Andreas Swanepoel ( $\sim$ pieterswanepoel@sun.ac.za )

Stellenbosch University Faculty of AgriSciences https://orcid.org/0000-0002-6481-0673

\section{Manuscript}

Keywords: cereals, cover crops, grazing, hay, legumes, wheat, crop rotation

Posted Date: February 3rd, 2021

DOI: https://doi.org/10.21203/rs.3.rs-174522/v1

License: (c) (1) This work is licensed under a Creative Commons Attribution 4.0 International License. Read Full License

Version of Record: A version of this preprint was published at Plant and Soil on February 6th, 2021. See the published version at https://doi.org/10.1007/s11104-021-04864-6. 


\section{Abstract}

Purpose

Cover crops can provide multiple agroecosystem services to crops produced in conservation agriculture systems. South African grain producers in the Mediterranean climate region are reluctant to integrate cover crops in rainfed systems since cover crops replace cash crops leading to financial losses. Using cover crops as fodder can help cover input costs, while providing a range of advantageous services to the cropping system. The aim of this study was to investigate how cover crop mixtures and the utilisation of cover crops affect soil quality, the quality and quantity of the mulch as well as wheat (Triticum aestivum L.) produced in the subsequent year.

\section{Methods}

A two-year study was conducted in the Western Cape Province of South Africa. In Year 1, diverse legume and cerealbased cover crop mixtures were partially grazed, cut and material removed for haymaking, or left unutilised as a mulch. In Year 2, spring wheat (Triticum aestivum L.) was planted to investigate the effects of cover crop mixtures and utilisation method on subsequent spring wheat yield.

Results

Cover crops used as hay or for grazing did not affect $(P<0.05)$ grain yield of wheat that followed in rotation. Legumebased cover crop mixtures increased $(P<0.05)$ wheat grain protein content regardless of utilisation method. Soil quality and nitrogen content improved $(P<0.05)$ when cover crops were grazed.

\section{Conclusions}

Cover cropping can be used by South African grain producers as an important agronomic tactic to improve system productivity and support sustainable intensification of rainfed cropping systems.

\section{Introduction}

Crop rotation forms part of the set of management principles of conservation agriculture systems. However, in many rainfed crop rotation systems, it is challenging to incorporate sufficient crop diversity with cash crop options limited by soil and climatic conditions or markets (Swanepoel et al., 2016). This is particularly true for commercial field cropping systems under rainfed conditions. Incorporating diversity in cropping systems is a critical management strategy to ensure sustainability (MacLaren et al. 2019a). Nitrogen ( $\mathrm{N}$ )-fixing legumes are particularly important in this context (Adhikari, 2019; Zhao et al., 2020). Cover crops, which may or may not include legumes, have the potential to incorporate diversity in crop rotation systems and are defined as crops that are used in production systems for a function other than harvesting (MacLaren et al., 2019b). Key functions of cover crops include, inter alia, $\mathrm{N}$ fixation, protection of natural resources, prevention of nutrient leaching, enhancement of soil quality, management of pests or diseases, and weed control (Blanco-Canqui et al., 2015; Blanco-Canqui and Jasa 2019; MacLaren et al. 2021). Cover crops can be used to serve a variety of functions simultaneously (Andriarimalala et al., 2013).

Cover crops have successfully been integrated into conservation agriculture systems in different regions globally (Flower et al., 2012; Andriarimalala et al., 2013; Shelton et al. 2018; Rugare et al. 2019). In regions with Mediterranean climates, such as the south-western parts of Australia and South Africa, rainfed crop rotation systems are anchored in wheat (Tritcum aestivum L.) and barley (Hordeum vulgare L.) produced in rotation with other small grains, canola (Brassica napus L.), and various forage crops. These crops are usually established in autumn and harvested late in spring or early in summer. Since rainfall in Mediterranean climate environments is distributed poorly, and concentrated in the middle of 
winter, soil water in rainfed systems is depleted during grain filling stages (Ward et al., 2012). In the South African Mediterranean climate region, the hot dry summers are not conducive to production of either a crop or cover crop. Double-cropping is therefore not possible. Should cover crops be included in rainfed cropping systems in this region, cover cropping will be limited to the cool (rainy) season and directly compete with the establishment of a cash or forage crop in the cropping system. By substituting cash crops with cover crops, the income of a cash crop season is forfeited. This is the main reason why producers are reluctant to incorporate cover crops in rainfed cropping systems in the South African Mediterranean region.

Partial use of cover crops as fodder can help cover input costs while possibly providing a range of services that are advantageous to the production system (Andriarimalala et al., 2013). Integration of livestock in cropping systems holds in additional potential benefits, such as economic risk mitigation provided by enterprise diversification (Bell et al., 2018) and weed control (MacLaren et al., 2019b). If cover crops are utilised by livestock, enough plant material should remain as a mulch to provide adequate soil cover. The aim of this study was to investigate how cover crops and the utilisation of cover crops affect the productivity of a crop rotation system under rainfed conditions in the South African Mediterranean climate region. The first objective was to evaluate the effect of cover crop utilisation on soil and the quality and quantity of the mulch. The second objective was to determine the effect of cover crop utilisation on yield of wheat planted in the subsequent production season.

\section{Materials And Methods}

\section{Experimental site description}

The study was conducted on Langgewens Research Farm located in the Swartland region (Western Cape Province, South Africa), in the 2016 and 2017 production seasons. The Swartland region is characterised by a Mediterranean climate with an average annual rainfall of $395 \mathrm{~mm}$ of which $80 \%$ occurs during the cooler half of the year (April to September). Eighty percent of the rainfall occurs during the months of April to September. During the 2016 season, the total average rainfall was $376 \mathrm{~mm}$ and in 2017 season received $238 \mathrm{~mm}$ (Fig. 1). In both 2016 and 2017 seasons, May and August were slightly warmer than the long-term mean temperature. In this region most of the crops are planted in April or May after the first rain has fallen and harvested from mid-October to November.

Figure 1: Long-term (LT) rainfall $(\mathrm{mm})$, mean minimum and maximum temperatures $\left({ }^{\circ} \mathrm{C}\right)$ of Langgewens Research Farm in the Swartland region of South Africa, as well as rainfall, minimum and maximum temperatures recorded monthly for both 2016 and 2017.

Wheat, barley, oats (Avena sativa L.), canola, lupines (Lupinus spp.) and forage crops such as annual medics (Medicago spp.) are typically produced in rainfed crop rotation systems integrated with livestock. Prior to the onset of this trial, crop production management was based on conservation agriculture principles, viz. a wheat-annual Medicago rotation, crop residue retention so that $>80 \%$ of soil surface is covered, and establishment of crops with a seed-drill (i.e., no-tillage). These conservation agriculture practices have been followed for more than 15 years. Sheep utilised the annual Medicago phase.

The soil types in the Western Cape Province varies considerably. At the trial site, soil forms included pedocutianic-lithic, eluvic-pedocutanic, pedocutanic-cumulic-hydromorphic and prismacutanic (IUSS Working Group, 2006). However, all soil types soil texture in the topsoil were classified as a sandy loam. Soil fertility indicators prior to the onset of the trial were within the recommended ranges for legumes (FERTASA, 2016), which are generally more sensitive than grain crops for soil nutrient deficiencies (Table 1).

\section{Experimental layout and treatments}


The experiment was laid out in a split-plot design with two factors. The whole plot factor (cover crop mixture) had two levels: legume-based and cereal-based cover crop mixtures. The subplot factor consisted of three different methods of utilising cover crops. Each treatment-combination was replicated in 12 blocks. Each of the 24 whole plots was $30 \mathrm{~m}$ in length and $15 \mathrm{~m}$ wide $\left(450 \mathrm{~m}^{2}\right)$. Whole plots were divided into three subplots of $150 \mathrm{~m}^{2}$ each $(10 \times 15 \mathrm{~m})$ to allow different utilisation methods.

The study was carried out during the 2016 (Year 1) and 2017 (Year 2) production seasons. The preceding crop was spring wheat. Following harvesting of the wheat, crop residues were retained and therefore carried over into the experimental year. In Year 1 of the experiment, two diverse cover crop mixtures (legume- and cereal-based; Table 2) were sown on 12 May 2016. Optimum planting date for crops in the Swartland region range between 1 and 31 May, depending on the onset of the rainy season. The legume- and cereal-based cover crop mixtures consisted of legume to cereal ratios based on seed number of 70:30 and 30:70, respectively. Species included in mixtures were adapted to the local climate and suitable for use by livestock. To explore the effect of cover crop utilisation on subsequent wheat yields, each cover crop mixture was subjected to different utilisation methods. For the first method of utilisation, cover crops were grazed by sheep. A fenced pen was assembled on each subplot subjected to grazing. Cover crops were grazed by sheep for 10 days when at least $85 \%$ of the cereal plants reached the flag-leaf growth stage (August). Two adult SA Mutton Merino ewes with an average body weight of $75 \mathrm{~kg}$ were allocated to each grazing subplot (i.e., $133 \mathrm{ewes} \mathrm{ha}^{-1}$ ). The second method of utilisation involved mowing of cover crops with an Agria bar mower (Agria-Werke $\mathrm{GmbH}$, Möckmühl, Germany) when $85 \%$ of the cereals plants reached the soft dough stage (September). The mowed material was raked and removed from the subplots and weighed to determine the removed biomass yield on dry matter basis for each subplot. When the regrowth from grazing or hay plots reached the ear-forming stage, all plots were terminated (October) with a contact herbicide (400 $\mathrm{g} \mathrm{ha}^{-1}$ paraquat) to prevent seed set. The third sub-plot utilisation treatment served as a control, viz. an unutilised cover crop. Cover crop material was kept as a mulch following termination with a crimping roller at the soft dough stage. 
Table 1

Soil fertility analysis of samples collected from the field site at a depth of 0-150 mm prior to planting legume and cereal-based cover crop mixtures. SE = Standard error

\begin{tabular}{|c|c|c|c|c|}
\hline \multirow[b]{2}{*}{ Soil parameter ${ }^{1}$} & \multicolumn{2}{|c|}{ Cereal-based mixture } & \multicolumn{2}{|c|}{ Legume-based mixture } \\
\hline & Mean & SE & Mean & SE \\
\hline $\mathrm{pH}(\mathrm{KCl})$ & 5.6 & 0.06 & 5.5 & 0.08 \\
\hline Resistance (ohm) & 393 & 43 & 429 & 47 \\
\hline Exchangeable $\mathrm{Ca}\left(\mathrm{mg} \mathrm{kg}^{-1}\right)$ & 860 & 22 & 827 & 64 \\
\hline Exchangeable $\mathrm{Mg}\left(\mathrm{mg} \mathrm{kg}^{-1}\right)$ & 120 & 4.3 & 135 & 15 \\
\hline Exchangeable $\mathrm{Na}\left(\mathrm{mg} \mathrm{kg}^{-1}\right)$ & 49 & 5.1 & 43 & 5.0 \\
\hline Exchangeable $\mathrm{K}\left(\mathrm{mg} \mathrm{kg}^{-1}\right)$ & 165 & 10 & 158 & 10 \\
\hline Cation exchange capacity (cmol kg-1) & 6.1 & 0.20 & 6.1 & 0.43 \\
\hline Extractable P $\left(\mathrm{mg} \mathrm{kg}^{-1}\right)$ & 70 & 7.4 & 75 & 6.2 \\
\hline Exchangeable $S\left(\mathrm{mg} \mathrm{kg}^{-1}\right)$ & 23 & 2.4 & 19 & 2.0 \\
\hline Extractable Cu (mg kg $\left.{ }^{-1}\right)$ & 1.2 & 0.09 & 1.4 & 0.16 \\
\hline Extractable Zn (mg kg $\left.{ }^{-1}\right)$ & 1.7 & 0.16 & 1.9 & 0.14 \\
\hline Extractable Mn (mg kg-1) & 49 & 7.2 & 82 & 13 \\
\hline Exchangeable $B\left(\mathrm{mg} \mathrm{kg}^{-1}\right)$ & 0.5 & 0.03 & 0.50 & 0.05 \\
\hline Organic C (\%) & 1.4 & 0.07 & 1.4 & 0.11 \\
\hline
\end{tabular}

In Year 2, spring wheat (cv. SST 056) was planted on 9 May 2017 across all plots to investigate the effects of cover crop mixtures and utilisation on subsequent spring wheat yield. A control treatment was included, in which wheat was grown in monoculture for two production seasons (2015 and 2016) prior to Year 2. 
Table 2

Composition of the legume- and cereal-based cover crop mixtures, cultivars used and seeding rates of each crop in the mixture.

\begin{tabular}{|llll|}
\hline Crop & Species name & Cultivar & Seeding rate \\
& & & (kg ha $\mathbf{~}^{\mathbf{1}} \mathbf{)}$ \\
\hline Legume-based mixture & & & \\
\hline Forage barley & Hordeum vulgare & SVG 13 & 6 \\
\hline Forage barley & Hordeum vulgare & Moby & 6 \\
\hline Triticale & x Triticosecale & US 2014 & 12.5 \\
\hline Field pea & Pisum sativum & Arvika & 35 \\
\hline Vetch & Vicia sativa & Haymaker & 3 \\
\hline Arrowleaf clover & Trifolium vesiculsum & Zulu II & 1 \\
\hline Berseem clover & Trifolium alexandrinum & Elite & 2 \\
\hline Subterranean clover & Trifolium subterraneum & Woogenellup & 2 \\
\hline Biserrula & Biserrula pelecinus & Casbah & 1 \\
\hline Cereal-based mixture & & & 25 \\
\hline Forage barley & Hordeum vulgare & SVG 13 & 25 \\
\hline Triticale & x Triticosecale & US 2014 & 50 \\
\hline Peas & Pisum sativum & Arvika & 20 \\
\hline Vetch & Vicia sativa & Haymaker & 3 \\
\hline Arrowleaf clover & Trifolium vesiculsum & Zulu II & 2 \\
\hline
\end{tabular}

\section{Trial management}

In both experimental years, 21 days prior to planting, plots were sprayed with the non-selective herbicide glyphosate at $720 \mathrm{~g} \mathrm{ha}^{-1}$. A double disc seed-drill with a row spacing of $254 \mathrm{~mm}$ was used to plant the crops. Fertiliser was bandplaced in the cover crop row at $2.5 \mathrm{~kg} \mathrm{~N} \mathrm{ha}^{-1}, 10 \mathrm{~kg} \mathrm{P} \mathrm{ha}^{-1}$ and $5 \mathrm{~kg} \mathrm{~K} \mathrm{ha}^{-1}$. Cover crops received no additional fertilisers during the rest of the cropping season. Wheat in Year 2 received $10 \mathrm{~kg} \mathrm{~N} \mathrm{ha}^{-1}, 7 \mathrm{~kg} \mathrm{P} \mathrm{ha}^{-1}, 3.5 \mathrm{~kg} \mathrm{~K} \mathrm{ha}^{-1}$ and $1.6 \mathrm{~kg} \mathrm{~S}^{-1}$ $\mathrm{ha}^{-1}$ with establishment, in the row. A topdressing was applied when $85 \%$ of wheat plants reached the four-leaf stage consisting of $40 \mathrm{~kg} \mathrm{~N} \mathrm{ha}^{-1}, 5 \mathrm{~kg} \mathrm{Pha}^{-1}$ and $6 \mathrm{~kg} \mathrm{~S} \mathrm{ha}^{-1}$. A foliar application of $150 \mathrm{~g}$ boron ha- ${ }^{-1}$ was applied at flagleaf stage. Wheat plots were kept disease and weed-free according to best practice in the region, mostly making use of chemical pesticides.

\section{Cover crop sampling (Year 1)}

Percentage soil cover was determined using an experimental pin meter at the end of the season (November) as described by Swanepoel et al. (2018). Cover crop biomass samples were collected at the same stage by cutting biomass at the soil surface from three $0.25 \mathrm{~m}^{2}$ quadrats per subplot. The three samples per subplot were pooled and fractionated into four groups, viz. leguminous cover crops, cereal cover crops, weeds, and wheat stubble left standing from the previous season. Samples were oven-dried at $60^{\circ} \mathrm{C}$ until constant weight and botanical composition was subsequently determined. The different fractions per dried sample were combined for herbage quality analyses. Samples were milled 
until particles could pass a 1-mm mesh. The determination of the nutrient element content of biomass was based on the methods described by AgriLASA (2007).

\section{Wheat sampling (Year 2)}

Prior to wheat planting, cover crop residue samples were collected from each plot following the same sampling strategy as in Year 1, except that botanical composition was not determined. Wheat plant population (plants $\mathrm{m}^{-2}$ ) was determined 40 days after planting by counting the number of wheat plants in ten 1-m rows per subplot. Biomass samples were taken at physiological maturity of wheat (November). Nutrient element content of the biomass was determined as described for samples taken in Year 1. Wheat grain yield was determined using a small plot-combine. Representative grain samples were taken from each plot to determine hectolitre mass, grain protein content, screenings and thousand seed weight.

\section{Soil sampling and analyses}

Five composited soil cores (45 mm in diameter) were collected per subplot to a depth of $150 \mathrm{~mm}$ in November of Year 1 , prior to establishment of wheat in May of Year 2 and in November of Year 2. Standard soil fertility tests were performed following methods described by the Non-Affiliated Soil Analysis Work Committee (1990). Results are not shown as there were no treatment effects and nutrients were within the required ranges for crop production. Soil quality tests were conducted on soil samples taken at the end of Year 1 according to the methods described by Haney et al. (2018). Soil quality indicators included soil organic matter, total N, inorganic N, organic N, N mineralisation, C:N ratio, total P, organic P, P mineralisation and aggregate stability.

\section{Statistical analyses}

For the data collected in Year 1, mixed models were used to analyse the effects of the two cover crop mixtures and three cover crop utilisation methods. The fixed effects in the model were specified as the cover crop mixture and cover crop utilisation method, and interactions amongst the mixtures and utilisations. Random effects in the model were specified as the blocks, as well as the interaction between block and mixture. The Bonferroni test was used as a post-hoc test to determine any significant differences between treatment means. The Bonferroni test is very conservative when a large number of group means are being compared. Because the Fisher's Least Significant Difference (LSD) test is less strict, it was only used to indicate significant differences when the Bonferroni test indicated significant differences at $P<0.05$. For the data collected in Year 1, residuals followed a normal distribution and variances were homogenous. In Year 2, some parameter residuals did not follow a normal distribution and the Games-Howel post-hoc test was used as a nonparametric test to confirm the results of the Bonferroni test. The Variance Estimation, Precision and Comparison (VEPAC) package of Statistica Version 13 (TIBCO Software, 2017) was used.

\section{Results}

\section{Effect of cover crop utilisation on mulch quantity and quality}

The cereal-based mixture produced more $(P<0.05)$ cereal- and total cover crop biomass when unutilised, compared to the unutilised cover crops in the legume-based mixture (Fig. 2). As cereals are generally more productive than legumes, the larger proportion of cereals in the cereal-based mixture explains the higher total biomass production $(P<0.05)$ in the cereal-based mixture. Grazing and haymaking resulted in a total cover crop biomass yield by the end of the season of 2367 and $1510 \mathrm{~kg} \mathrm{ha}^{-1}$, respectively, compared to the unutilised treatment's biomass production of $3304 \mathrm{~kg} \mathrm{ha}^{-1}$. Although the percentage of soil covered by the end of the season was higher $(P<0.05)$ for the unutilised plots (98 to $99 \%$ ) compared to cover crops utilised through grazing or haymaking (83 to $85 \%$ ), all treatment-combinations were still 
covering the soil sufficiently (results not shown). Weed pressure was low, and therefore soil was mostly covered by cover crop material.

The total nutrient element stocks per hectare are presented in Table 3. The stocks of all nutrients (except $P$ ) in the legume-based mixture was similar $(P>0.05)$ when the cover crop mixture was unutilised and grazed. When cover crop biomass was removed for hay, lower $(P<0.05)$ nutrient stocks (except Fe) were recorded than for the unutilised cover crop mixtures. In the cereal-based mixture there was generally a more gradual decline $(P<0.05)$ for most nutrient stocks. The unutilised cover crops had the highest nutrient stocks, grazing was intermediate and the lowest nutrient stocks were observed when hay was produced $(P<0.05)$.

The nutrient content of soil cover and total aboveground cover crop biomass that was present prior to establishment of wheat in the subsequent year, within each treatment, are shown in Table 4. The mulch load of unutilised cover crop treatments was comparable $(P>0.05)$ to the mulch load of a previous wheat crop (control). The grazing and hay treatments resulted in lower $(P<0.05)$ mulch loads compared to the control. However, the nutrient stocks in the grazing and hay treatments' mulch were similar $(P>0.05)$ to the control, except for Na for which the grazed leguminous treatment recorded a higher $(p<0.05)$ Na content. By the end of the Year 2 , all treatments had a similar mulch load and nutrient content, except for Al (Table 5). Nutritional value of the two cover crop mixes was similar $(P<0.05)$, except for neutral detergent fibre content that was lower for the leguminous mixture (results not shown).

\section{Effect of cover crop utilisation on soil quality}

The effects of cover crop mixtures and utilisations on soil quality by the end of the cover crop growing season are presented in Table 6. Soil organic matter content was not affected $(P>0.05)$ by any treatment factor, which was expected as it takes multiple years to observe effect on soil organic matter content. The unutilised cover crop mixture had the lowest $(P<0.05)$ total $\mathrm{N}$ and inorganic $\mathrm{N}$ contents. Except for $\mathrm{N}$ mineralisation in soil of the leguminous mixture the unutilised cover crop mixtures had the lowest $(P<0.05)$ mineralisable $\mathrm{N}$ content. Organic $\mathrm{N}$ was not affected $(P>$ 0.05 ) by cover crop treatments. However, when a leguminous mixture was utilised either through grazing or haymaking, it had high $(P<0.05) \mathrm{N}$-related soil properties. The cereal-based mixture's total $\mathrm{N}$ and inorganic $\mathrm{N}$ contents were also among the highest $(P<0.05)$ when they were grazed, but not when used for haymaking. In general, higher $(P<0.05) \mathrm{N}-$ related properties were observed for the leguminous mixture, which is expected, although it did not always differ $(P>$ 0.05) from that of the cereal mixtures.

Organic $\mathrm{P}$ content of soil was among the highest $(P<0.05)$ in the leguminous mixture, irrespective of utilisation. Similar trends were observed for total $\mathrm{P}$ content and $\mathrm{P}$ mineralisation, although haymaking and grazing of the cereal mixture sometimes resulted in similar $(P>0.05)$ responses.

The unutilised subplots of the cereal-based mixture had a higher $(p<0.05)$ aggregate stability compared to the grazed subplots, likely due to the fibrous nature of cereal root systems. 
Table 3

Nutrient element content of the total above-ground biomass following the cover crop growing season for each subplot (hay, grazed and utilised) in the legume- and cereal-based cover crop mixtures.

Different letters indicate significant differences $(P<0.05)$ within a mixture. $\mathrm{SE}=$ standard error; $\mathrm{CV}=$ Coefficient of variation

\begin{tabular}{|c|c|c|c|c|c|}
\hline & Hay & Grazing & Unutilised & SE & CV \\
\hline \multicolumn{6}{|c|}{ Cereal-based mixture } \\
\hline Ash $\left(\mathrm{kg} \mathrm{ha}^{-1}\right)$ & $176^{\mathrm{b}}$ & $258^{a}$ & $310^{\mathrm{a}}$ & 30.07 & 45.01 \\
\hline $\mathrm{N}\left(\mathrm{kg} \mathrm{ha}^{-1}\right)$ & $29.65^{c}$ & $51.95^{b}$ & $72.16^{a}$ & 5.11 & 43.47 \\
\hline $\mathrm{Ca}\left(\mathrm{kg} \mathrm{ha}^{-1}\right)$ & $9.09^{b}$ & $10.11^{b}$ & $15.52^{\mathrm{a}}$ & 1.35 & 43.42 \\
\hline$P\left(\mathrm{~kg} \mathrm{ha}^{-1}\right)$ & $4.39^{c}$ & $6.75^{b}$ & $11.22^{\mathrm{a}}$ & 0.64 & 43.39 \\
\hline $\operatorname{Mg}\left(\mathrm{kg} \mathrm{ha}^{-1}\right)$ & $2.85^{c}$ & $4.88^{b}$ & $7.15^{\mathrm{a}}$ & 0.51 & 44.53 \\
\hline $\mathrm{K}\left(\mathrm{kg} \mathrm{ha}^{-1}\right)$ & $27.04^{\mathrm{C}}$ & $51.80^{\mathrm{b}}$ & $73.59^{a}$ & 5.06 & 47.02 \\
\hline $\mathrm{Na}\left(\mathrm{kg} \mathrm{ha}^{-1}\right)$ & $2.33^{b}$ & $4.71^{a b}$ & $7.61^{a}$ & 1.92 & 116 \\
\hline $\mathrm{Fe}\left(\mathrm{kg} \mathrm{ha}^{-1}\right)$ & $2.08^{a}$ & $2.22^{\mathrm{a}}$ & $1.74^{\mathrm{a}}$ & 0.37 & 59.35 \\
\hline $\mathrm{S}\left(\mathrm{kg} \mathrm{ha}^{-1}\right)$ & $2.38^{\mathrm{c}}$ & $4.05^{b}$ & $5.72^{\mathrm{a}}$ & 0.46 & 46.51 \\
\hline $\mathrm{Al}\left(\mathrm{kg} \mathrm{ha}^{-1}\right)$ & $1.04^{a}$ & $1.16^{\mathrm{a}}$ & $1.11^{\mathrm{a}}$ & 0.14 & 43.52 \\
\hline $\operatorname{Mn}\left(\mathrm{g} \mathrm{ha}^{-1}\right)$ & $88.02^{b}$ & $112.1^{b}$ & $179.2^{\mathrm{a}}$ & 13.63 & 42.92 \\
\hline $\mathrm{Cu}\left(\mathrm{g} \mathrm{ha}^{-1}\right)$ & $10.60^{c}$ & $17.10^{\mathrm{b}}$ & $22.46^{\mathrm{a}}$ & 2.11 & 50.85 \\
\hline $\mathrm{Zn}\left(\mathrm{g} \mathrm{ha} \mathrm{a}^{-1}\right)$ & $33.49^{c}$ & $54.31^{b}$ & $80.27^{a}$ & 5.20 & 41.59 \\
\hline $\mathrm{B}\left(\mathrm{g} \mathrm{ha}^{-1}\right)$ & $23.73^{b}$ & $24.91^{b}$ & $37.15^{\mathrm{a}}$ & 3.22 & 40.43 \\
\hline \multicolumn{6}{|c|}{ Legume-based mixture } \\
\hline Ash $\left(\mathrm{kg} \mathrm{ha}^{-1}\right)$ & $190^{\mathrm{b}}$ & $271^{a}$ & $297^{a}$ & 30.07 & 45.01 \\
\hline$N\left(\mathrm{~kg} \mathrm{ha}^{-1}\right)$ & $39.04^{b}$ & $72.51^{a}$ & $73.86^{a}$ & 5.11 & 43.47 \\
\hline $\mathrm{Ca}\left(\mathrm{kg} \mathrm{ha}^{-1}\right)$ & $12.70^{b}$ & $19.93^{a}$ & $20.51^{a}$ & 1.35 & 43.42 \\
\hline $\mathrm{P}\left(\mathrm{kg} \mathrm{ha}^{-1}\right)$ & $5.05^{c}$ & $7.98^{b}$ & $10.01^{a}$ & 0.64 & 43.39 \\
\hline $\mathrm{Mg}\left(\mathrm{kg} \mathrm{ha}^{-1}\right)$ & $3.80^{b}$ & $6.67^{a}$ & $7.39^{a}$ & 0.51 & 44.53 \\
\hline $\mathrm{K}\left(\mathrm{kg} \mathrm{ha}^{-1}\right)$ & $31.96^{b}$ & $53.3^{a}$ & $63.44^{\mathrm{a}}$ & 5.06 & 47.02 \\
\hline $\mathrm{Na}\left(\mathrm{kg} \mathrm{ha}^{-1}\right)$ & $3.13^{b}$ & $10.60^{a}$ & $8.08^{a}$ & 1.92 & 116 \\
\hline $\mathrm{Fe}\left(\mathrm{kg} \mathrm{ha}^{-1}\right)$ & $1.96^{\mathrm{a}}$ & $2.86^{\mathrm{a}}$ & $2.11^{\mathrm{a}}$ & 0.37 & 59.35 \\
\hline$S\left(k g h a^{-1}\right)$ & $3.01^{b}$ & $5.05^{\mathrm{a}}$ & $5.50^{a}$ & 0.46 & 46.51 \\
\hline
\end{tabular}




\begin{tabular}{|c|c|c|c|c|c|}
\hline & Hay & Grazing & Unutilised & SE & CV \\
\hline $\mathrm{Al}\left(\mathrm{kg} \mathrm{ha}^{-1}\right)$ & $1.10^{\mathrm{b}}$ & $1.68^{a}$ & $1.08^{b}$ & 0.14 & 43.52 \\
\hline $\operatorname{Mn}\left(\mathrm{gha}^{-1}\right)$ & $100.6^{b}$ & $156.0^{a}$ & $162.2^{\mathrm{a}}$ & 13.63 & 42.92 \\
\hline $\mathrm{Cu}\left(\mathrm{gha}^{-1}\right)$ & $10.86^{b}$ & $17.15^{a}$ & $20.82^{a}$ & 2.11 & 50.85 \\
\hline $\mathrm{Zn}\left(\mathrm{gha}^{-1}\right)$ & $41.09^{b}$ & $67.88^{a}$ & $70.82^{a}$ & 5.20 & 41.59 \\
\hline$B\left(g h a^{-1}\right)$ & $28.94^{b}$ & $45.26^{a}$ & $41.56^{a}$ & 3.22 & 40.43 \\
\hline
\end{tabular}


Table 4

Soil nutrient content (0-150 mm depth) and crop residue load before the onset of the wheat growing season (May 2017;

Year 2). The treatments consisted of wheat planted on plots previously planted to cover crop mixtures based on legumes or cereals. Each mixture was utilised as hay, for grazing or left unutilised. No common letter within a row denotes a significant difference $(p<0.05)$. SE = standard error; $C V=$ coefficient of variation

\begin{tabular}{|c|c|c|c|c|c|c|c|c|c|}
\hline & \multicolumn{3}{|c|}{ Cereal-based mixture } & \multicolumn{3}{|c|}{ Legume-based mixture } & \multirow{2}{*}{$\begin{array}{l}\text { Wheat } \\
\text { monoculture }\end{array}$} & \multirow[t]{2}{*}{ SE } & \multirow[t]{2}{*}{ CV } \\
\hline & Hay & Grazing & Unutilised & Hay & Grazing & Unutilised & & & \\
\hline $\begin{array}{l}\text { Crop } \\
\text { residue } \\
\text { load (kg } \\
\mathrm{ha}^{-1} \text { ) }\end{array}$ & $2188^{c}$ & $2333^{b c}$ & $3759^{a}$ & $2072^{c}$ & $2306^{c}$ & $3217^{a b}$ & $3265^{a}$ & 347 & 78.22 \\
\hline $\begin{array}{l}\mathrm{N}\left(\mathrm{kg} \mathrm{ha}^{-}\right. \\
\left.{ }^{1}\right)\end{array}$ & $32.28^{c}$ & $37.09^{b c}$ & $54.77^{a}$ & $29.28^{c}$ & $36.53^{b c}$ & $48.47^{a b}$ & $36.44^{\mathrm{bc}}$ & 5.83 & 83.72 \\
\hline $\begin{array}{l}P\left(\mathrm{~kg} \mathrm{ha}^{-}\right. \\
\left.{ }^{1}\right)\end{array}$ & $4.07^{\mathrm{bc}}$ & $4.39^{b c}$ & $7.56^{a}$ & $3.15^{c}$ & $4.19^{b c}$ & $6.08^{a b}$ & $3.81^{c}$ & 0.78 & 95.88 \\
\hline $\begin{array}{l}\mathrm{K}\left(\mathrm{kg} \mathrm{ha}^{-}\right. \\
\left.{ }^{1}\right)\end{array}$ & $12.40^{\mathrm{bc}}$ & $10.10^{b c}$ & $23.67^{a}$ & $5.37^{c}$ & $8.88^{c}$ & $18.41^{a b}$ & $12.79^{b c}$ & 3.05 & 124 \\
\hline $\begin{array}{l}\text { Ca (kg ha- } \\
\left.{ }^{1}\right)\end{array}$ & $10.07^{b}$ & $11.44^{\mathrm{b}}$ & $13.90^{\mathrm{ab}}$ & $11.61^{b}$ & $14.35^{\mathrm{ab}}$ & $17.36^{a}$ & $10.56^{b}$ & 1.87 & 78.13 \\
\hline $\begin{array}{l}\mathrm{Mg}(\mathrm{kg} \\
\left.\mathrm{ha}^{-1}\right)\end{array}$ & $2.69^{c}$ & $3.14^{\mathrm{bc}}$ & $4.56^{a}$ & $2.25^{c}$ & $3.48^{\mathrm{abc}}$ & $4.24^{\mathrm{ab}}$ & $2.86^{c}$ & 0.50 & 85.87 \\
\hline $\begin{array}{l}\text { Al (kg ha- } \\
\text { 1) }\end{array}$ & $2.88^{a}$ & $4.16^{a}$ & $3.50^{\mathrm{a}}$ & $3.35^{\mathrm{a}}$ & $3.72^{\mathrm{a}}$ & $4.00^{a}$ & $3.88^{a}$ & 0.70 & 47.12 \\
\hline $\begin{array}{l}\mathrm{S}\left(\mathrm{kg} \mathrm{ha}^{-}\right. \\
\left.{ }^{1}\right)\end{array}$ & $2.29^{c}$ & $2.57^{b c}$ & $3.95^{a}$ & $1.90^{c}$ & $2.52^{b c}$ & $3.51^{\mathrm{ab}}$ & $2.80^{a b c}$ & 0.45 & 91.96 \\
\hline $\begin{array}{l}\text { Cu (g ha- } \\
\left.{ }^{1}\right)\end{array}$ & 6.15 & 8.55 & 9.31 & 6.84 & 7.28 & 8.48 & 7.06 & 1.36 & 64.34 \\
\hline $\begin{array}{l}\mathrm{Zn}\left(\mathrm{gha} \mathrm{a}^{-}\right. \\
\left.{ }^{1}\right)\end{array}$ & $38.68^{c}$ & $50.75^{a b c}$ & $64.15^{a}$ & $36.04^{c}$ & $47.72^{b c}$ & $58.97^{a b}$ & $41.56^{c}$ & 5.44 & 80.64 \\
\hline $\begin{array}{l}\text { Mn (g ha- } \\
\left.{ }^{1}\right)\end{array}$ & $106^{b}$ & $162^{a b}$ & $161^{a b}$ & $111^{b}$ & $148^{a b}$ & $194^{a}$ & $177^{\mathrm{ab}}$ & 29.03 & 70.94 \\
\hline$B\left(g h a^{-1}\right)$ & $16.18^{b}$ & $21.75^{a b}$ & $22.44^{a b}$ & $16.63^{b}$ & $23.12^{\mathrm{ab}}$ & $25.68^{a}$ & $17.25^{b}$ & 3.08 & 69.96 \\
\hline $\begin{array}{l}\mathrm{Na}\left(\mathrm{g} \mathrm{ha}^{-}\right. \\
\left.{ }^{1}\right)\end{array}$ & $1098^{\mathrm{abc}}$ & $931^{b c d}$ & $1685^{\mathrm{ab}}$ & $609^{d}$ & $1506^{\mathrm{abc}}$ & $1936^{a}$ & $740^{\mathrm{cd}}$ & 304 & 123 \\
\hline
\end{tabular}


Table 5

Soil nutrient content (0-150 mm depth) and crop residue load by the end of Year 2 (Nov 2017). The treatments consisted of wheat planted on plots previously planted to a cover crop mixture based on legumes or cereals. Each mixture was utilised as hay, for grazing or left unutilised. No common letter within a row denotes a significant difference $(P<0.05)$.

$\mathrm{SE}=$ standard error; $\mathrm{CV}=$ coefficient of variation

\begin{tabular}{|c|c|c|c|c|c|c|c|c|c|}
\hline & \multicolumn{3}{|c|}{ Cereal-based mixture } & \multicolumn{2}{|c|}{$\begin{array}{l}\text { Legume-based } \\
\text { mixture }\end{array}$} & \multicolumn{2}{|c|}{ Wheat monoculture } & \multirow[t]{2}{*}{ SE } & \multirow[t]{2}{*}{ CV } \\
\hline & Hay & Grazing & Unutilised & Hay & Grazing & Unutilis & & & \\
\hline $\begin{array}{l}\text { Crop } \\
\text { residue } \\
\text { load(kg } \\
\left.\mathrm{ha}^{-1}\right)\end{array}$ & 244 & 441 & 787 & 531 & 511 & 539 & 1011 & 347 & 78.22 \\
\hline $\begin{array}{l}\mathbf{N}(\mathbf{k g} \\
\left.\mathrm{ha} \mathrm{a}^{-1}\right)\end{array}$ & 2.89 & 6.18 & 10.35 & 8.07 & 7.35 & 7.57 & 9.94 & 5.83 & 83.72 \\
\hline $\begin{array}{l}\mathrm{P}(\mathrm{kg} \\
\left.\mathrm{ha} \mathrm{a}^{-1}\right)\end{array}$ & 0.28 & 0.53 & 1.04 & 0.78 & 0.72 & 0.71 & 0.88 & 0.78 & 95.88 \\
\hline $\begin{array}{l}\mathrm{K}(\mathrm{kg} \\
\left.\mathrm{ha}^{-1}\right)\end{array}$ & 0.48 & 0.85 & 1.82 & 1.26 & 1.14 & 1.22 & 1.71 & 3.05 & 124 \\
\hline $\begin{array}{l}\mathrm{Ca}(\mathrm{kg} \\
\left.\mathrm{ha} \mathrm{a}^{-1}\right)\end{array}$ & 1.25 & 2.21 & 3.73 & 3.07 & 2.76 & 2.62 & 3.69 & 1.87 & 78.13 \\
\hline $\begin{array}{l}\mathrm{Mg}(\mathrm{kg} \\
\left.\mathrm{ha}^{-1}\right)\end{array}$ & 0.23 & 0.44 & 0.85 & 0.64 & 0.62 & 0.61 & 0.87 & 0.50 & 85.87 \\
\hline $\begin{array}{l}\mathrm{Al}(\mathrm{kg} \\
\left.\mathrm{ha}^{-1}\right)\end{array}$ & $1.03^{b}$ & $2.08^{\mathrm{ab}}$ & $2.88^{a b}$ & $2.62^{\mathrm{ab}}$ & $2.45^{\mathrm{ab}}$ & $2.65^{\mathrm{ab}}$ & $3.33^{\mathrm{a}}$ & 0.70 & 47.12 \\
\hline $\begin{array}{l}\text { S (kg } \\
\left.\mathrm{ha}^{-1}\right)\end{array}$ & 0.17 & 0.33 & 0.59 & 0.43 & 0.41 & 0.39 & 0.60 & 0.45 & 91.96 \\
\hline $\begin{array}{l}\mathrm{Cu}(\mathrm{g} \\
\left.\mathrm{ha} \mathrm{a}^{-1}\right)\end{array}$ & 1.27 & 2.21 & 3.34 & 2.65 & 2.87 & 2.85 & 3.70 & 1.36 & 64.34 \\
\hline $\begin{array}{l}\mathrm{Zn}(\mathrm{g} \\
\left.\mathrm{h} \mathrm{a}^{-1}\right)\end{array}$ & 3.34 & 5.84 & 11.75 & 9.85 & 8.91 & 9.06 & 12.29 & 5.44 & 80.64 \\
\hline $\begin{array}{l}\mathrm{Mn}(\mathrm{g} \\
\left.\mathrm{ha}{ }^{-1}\right)\end{array}$ & 20.46 & 39.65 & 54.19 & 46.04 & 63.19 & 50.57 & 76.93 & 29.03 & 70.94 \\
\hline $\begin{array}{l}B(g \\
\left.h a^{-1}\right)\end{array}$ & 2.32 & 5.06 & 7.86 & 5.59 & 6.02 & 5.58 & 8.01 & 3.08 & 69.96 \\
\hline $\begin{array}{l}\mathrm{Na}(\mathrm{g} \\
\left.\mathrm{ha} \mathrm{a}^{-1}\right)\end{array}$ & 49.51 & 77.32 & 172.55 & 120.30 & 98.40 & 119.11 & 168.64 & 304 & 123 \\
\hline
\end{tabular}


Table 6

Soil quality indicators after a cover crop growing season for soil collected at a 0-150 mm depth layer. Legume and cereal-based cover crop mixtures were used for haymaking, grazing, or left unutilised. No common superscript letter indicates significant differences $(\mathrm{p}<0.05)$ within a row. $\mathrm{SE}=$ standard error; $\mathrm{CV}=$ Coefficient of variation

\begin{tabular}{|c|c|c|c|c|c|c|c|c|}
\hline & \multicolumn{3}{|c|}{ Cereal-based mixture } & \multicolumn{3}{|c|}{ Legume-based mixture } & \multirow[t]{2}{*}{ SE } & \multirow[t]{2}{*}{ CV } \\
\hline & Hay & Grazing & Unutilised & Hay & Grazing & Unutilised & & \\
\hline Soil organic matter (\%) & 2.43 & 2.48 & 2.47 & 2.36 & 2.33 & 2.28 & 0.11 & 15.06 \\
\hline Total $\mathbf{N}\left(\mathrm{mg} \mathrm{kg}^{-1}\right)$ & $18.63^{b c}$ & $18.95^{\mathrm{abc}}$ & $16.38^{c}$ & $21.05^{\mathrm{ab}}$ & $22.91^{\mathrm{a}}$ & $18.9 b^{c}$ & 1.48 & 27.46 \\
\hline Inorganic $\mathbf{N}\left(\mathrm{mg} \mathrm{kg}^{-1}\right)$ & $7.33^{\mathrm{bc}}$ & $8.69^{a b}$ & $5.22^{c}$ & $8.95^{\mathrm{ab}}$ & $11.09^{a}$ & $7.04^{\mathrm{bc}}$ & 1.03 & 48.33 \\
\hline Organic $\mathbf{N}\left(\mathrm{mg} \mathrm{kg}^{-1}\right)$ & 11.74 & 11.63 & 11.29 & 13.03 & 13.28 & 12.92 & 0.90 & 25.33 \\
\hline $\mathrm{N}$ mineralisation $\left(\mathrm{mg} \mathrm{kg}^{-1}\right)$ & $3.58^{\mathrm{ab}}$ & $2.78^{b}$ & $2.55^{\mathrm{b}}$ & $5.27^{a}$ & $4.28^{\mathrm{ab}}$ & $4.32^{\mathrm{ab}}$ & 0.84 & 78.26 \\
\hline C:N ratio & $16.19^{a b}$ & $16.81^{a b}$ & $17.27^{a}$ & $14.91^{b}$ & $15.08^{a b}$ & $15.64^{\mathrm{ab}}$ & 0.82 & 18.02 \\
\hline Total P (mg kg-1) & $30^{\mathrm{ab}}$ & $28.5^{\mathrm{ab}}$ & $27^{b}$ & $34.58^{a b}$ & $35.08^{a}$ & $33^{a b}$ & 4.05 & 44.25 \\
\hline Organic P (mg kg $\left.{ }^{-1}\right)$ & $6.46^{\mathrm{bc}}$ & $6.48^{\mathrm{bc}}$ & $6.21^{c}$ & $7.11^{\mathrm{ab}}$ & $7.34^{\mathrm{a}}$ & $6.93^{a b c}$ & 0.54 & 27.27 \\
\hline P mineralisation $\left(\mathrm{mg} \mathrm{kg}^{-1}\right)$ & $2.12^{\mathrm{ab}}$ & $1.39^{b}$ & $1.23^{b}$ & $3.50^{\mathrm{a}}$ & $2.78^{a b}$ & $2.66^{\mathrm{ab}}$ & 0.68 & 106 \\
\hline Aggregate stability (\%) & $19.83^{\mathrm{ab}}$ & $16.75^{\mathrm{b}}$ & $21.83^{a}$ & $21.42^{\mathrm{ab}}$ & $21.83^{a b}$ & $22.67^{\mathrm{ab}}$ & 2.68 & 44.25 \\
\hline
\end{tabular}

Table 7

Wheat productivity, yield and quality analyses by the end of the growing season (Year 2). The treatments consisted of wheat planted on plots previously planted to a cover crop mixture based on legumes or cereals. Each mixture was utilised as hay, for grazing or left unutilised. No common letter within a row denotes significant differences $(p<0.05)$. SE = standard error; $\mathrm{CV}=$ Coefficient of variation

\begin{tabular}{|c|c|c|c|c|c|c|c|c|c|}
\hline & \multicolumn{3}{|c|}{ Cereal-based mixture } & \multicolumn{3}{|c|}{ Legume-based mixture } & \multirow{2}{*}{$\begin{array}{l}\text { Wheat } \\
\text { monoculture }\end{array}$} & \multirow[t]{2}{*}{ SE } & \multirow[t]{2}{*}{ CV } \\
\hline & Hay & Grazing & Unutilised & Hay & Grazing & Unutilised & & & \\
\hline $\begin{array}{l}\text { Wheat } \\
\text { biomass (kg } \\
\mathrm{ha}^{-1} \text { ) }\end{array}$ & $4853^{a b}$ & $5475^{a b}$ & $4389^{b}$ & $6011^{a}$ & $5412^{a b}$ & $5366^{a b}$ & $5766^{a}$ & 423 & 17.03 \\
\hline $\begin{array}{l}\text { Grain yield } \\
\left(\mathrm{kg} \mathrm{ha}^{-1}\right)\end{array}$ & $2453^{a b}$ & $2387^{a b}$ & $2108^{b}$ & $2335^{a}$ & $2224^{\mathrm{ab}}$ & $2112^{a b}$ & $2580^{a}$ & 203 & 17.05 \\
\hline $\begin{array}{l}\text { Hectolitre } \\
\text { mass (kg hL- } \\
\left.{ }^{1}\right)\end{array}$ & $80.70^{b}$ & $80.05^{b}$ & $80.68^{b}$ & $80.45^{b}$ & $79.85^{b}$ & $79.80^{b}$ & $82.23^{a}$ & 0.50 & 1.47 \\
\hline $\begin{array}{l}\text { Protein } \\
\text { content (\%) }\end{array}$ & $13.98^{b}$ & $14.33^{b}$ & $13.38^{b}$ & $15.85^{a}$ & $15.85^{a}$ & $15.95^{a}$ & $13.80^{b}$ & 0.40 & 8.56 \\
\hline $\begin{array}{l}\text { Screenings } \\
\text { (\%) }\end{array}$ & $0.83^{\mathrm{ab}}$ & $0.78^{a b}$ & $0.75^{\mathrm{ab}}$ & $0.80^{\mathrm{ab}}$ & $0.85^{\mathrm{ab}}$ & $0.95^{a}$ & $0.65^{\mathrm{b}}$ & 0.07 & 19.25 \\
\hline $\begin{array}{l}\text { Thousand } \\
\text { seed mass }(\mathrm{g})\end{array}$ & 37.03 & 36.40 & 37.75 & 36.18 & 36.58 & 36.23 & 35.65 & 1.01 & 5.18 \\
\hline
\end{tabular}

Wheat establishment and production 
Establishment of wheat was acceptable for all treatments as between 85 and 111 plants $\mathrm{m}^{-2}$ established. No treatment effects $(P>0.05)$ for plant population were observed (results not shown). Wheat biomass was highest $(P<0.05)$ for the monoculture wheat treatment, intermediate for all other treatments and lowest $(P<0.05)$ where an unutilised cereal cover crop was previously planted (Table 7). Wheat grain yield ranged between 2108 and $2580 \mathrm{~kg} \mathrm{ha}^{-1}$, which are acceptable in this region for a relatively dry year (Fig. 1). Cover crop mixture and utilisation were similar $(P>0.05)$ to monoculture wheat, except when a cereal-based cover crop mixture was left unutilised, the subsequent wheat grain yield was lower $(P$ $<0.05)$ than monoculture wheat. Cover crop mixture and utilisation had a positive effect $(P<0.05)$ on wheat protein content of seed harvested from plots which previously had a legume-based mixture, regardless of the utilisation. Wheat monoculture had the highest $(P<0.05)$ hectolitre mass and the lowest $(p<0.05)$ percentage of screenings compared to the other treatments.

\section{Discussion}

Reducing the amount of aboveground cover crop biomass through haymaking or grazing needs to be done judiciously to retain the benefits provided by cover crops. In the current study, haymaking resulted in the lowest $(P<0.05)$ amount of aboveground cover crop biomass. Fisher et al. (2012) reported thresholds in similar climatic conditions of $1000 \mathrm{~kg} \mathrm{ha}^{-1}$ or $750 \mathrm{~kg} \mathrm{ha}^{-1}$ of cereal- or leguminous material to effectively prevent wind and water erosion. Optimal thresholds will, however, different across contexts and for different purposes and will be affected by quantity and quality of the residue (Shahbaz et al. 2017). It is therefore not clear what the thresholds are for a cover crop to perform various individual agro-

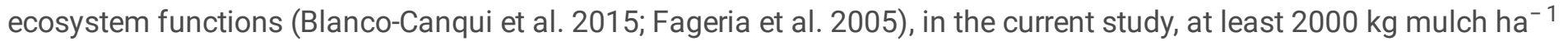
were recorded prior to establishment of the subsequent wheat crop. We therefore argue that 'enough' biomass was retained for the cover crop to perform multiple functions. One of the major agroecosystem functions of a soil cover in drier environments is prevention of soil water loss through evaporation (Ranaivoson et al. 2017; Haarhoff and Swanepoel 2020). Although it is expected that the benefits of an adequate soil cover would be most pronounced on yield of crops in dry years (Pittlekow et al., 2015), a wheat yield benefit was not observed in the current study, despite the dry wheat production season.

High mulch loads may interfere with crop establishment, growth, and development (Swanepoel et al. 2019) which might explain why wheat biomass and grain yield was lower $(P<0.05)$ when the mulch load was high (Tables 5 and 7$)$. It is important to establish critical thresholds of mulch or crop residue as redundant loads of mulch might interfere with crop production. Where high loads of biomass are produced, it would be advised to utilise the soil cover to some extend through grazing or haymaking (Andriarimalala et al., 2013), or light incorporation rather than just leaving cover crops on the surface as mulch.

Despite the reduction in the amount of cover crop residue because of utilisation, grazing had a smaller $(p<0.05)$ effect on the mulch load in comparison with hay production, this was due to regrowth following the grazing procedure. Regrowth was minimal following cutting material for hay as most crops were in early reproductive stages at the time. However, hay was cut at a time to ensure maximum hay quality. Although the mulch load for the hay treatments were lowest, it still exceeded $1500 \mathrm{~kg} \mathrm{ha}^{-1}$, which still covered the soil (Fig. 2). The mulch load may affect the amount of nutrients that are carried over to the subsequent season - nutrients which may become available to crops following decomposition of material. The stocks of nutrient elements (except $P$ ) in the legume-based mixture was similar $(P>0.05)$ when the cover crops were unutilised or grazed. This points to circulation of nutrients in the grazed system, allowing plants to uptake nutrients that flow via manure and urine back to soil. Grazing, and likely also haymaking, could be viewed as a way to facilitate nutrient cycling, either through root turnover and decomposition, or recycling of nutrients through manure and urine (Gardner and Faulkner, 1991). Grazing of cover crops improved $(P<0.05)$ soil N parameters compared to unutilised cover crops (Table 6). In a system where $\mathrm{N}$ is one of the most-limiting nutrients for wheat

Page 14/19 
production, an increase in soil $\mathrm{N}$ may lead to a yield or seed quality response, particularly in good rainfall years (Agenbag, 2012). The wheat grain protein content (i.e., grain $\mathrm{N}$ content) improved $(P<0.05)$ when it followed a legumebased mixture, irrespective of its utilisation. The breakdown of the mulch and subsequent mineralisation is also slower in cold and wet production conditions, hence the no-response reaction of the following wheat yield, but a positive response in wheat quality under grazing due to late mineralisation at the end of the production season when temperatures starts to rise. As a result of the nutrient carry-over, fertiliser use can potentially be reduced, particularly $\mathrm{N}$ fertilisers. Reduced use of fertilisers will have a positive effect on ecosystem function and agricultural profitability (Becker et al. 2020).

Overall, utilisation of cover crops in the form of grazing and hay production did not have a negative effect on soil quality, which was in agreement by Blanco-Canqui et al. (2015). In the no-tillage systems of southern Brazil, grazed cover crops improved soil quality if the cover crops were not overgrazed (de Faccio Carvalho et al., 2010). When cereal-based cover crop mixtures were unutilised, a higher $(p<0.05)$ aggregate stability were observed compared to the grazed subplots, likely due to the fibrous nature of cereal root systems. However, the potential of cereal-based cover crops to improve soil physical quality should be investigated further as the mechanisms in the current study were not explicitly clear. as there was a significant amount of cereal biomass in the legume-mixture.

It is important to maintain a balance between removal of material (grazing or haymaking) and maintaining a sufficient mulch layer to cover the soil. Andriarimalala et al. (2013) demonstrated the importance of utilising cover crops in smallholder farming systems in Madagascar to support sustainable income through livestock integration in cropping systems. We have seen that the cover crop utilisation methods affected soil chemical and bio-chemical processes and more research is necessary to investigate the effects of the different mixtures and utilisations on soil physical and biological processes. It is expected that cereal-based cover crops, being more productive, may have a bigger impact on soil physical properties over the long-term (Blanco-Canqui and Jasa 2019).

One of the main factors preventing farmers from converting to conservation agriculture is the financial loss (or opportunity cost) when crop residue is left as soil cover and not utilised (Giller et al., 2009). In this study the utilisation of cover crops reduced $(p<0.05)$ the amount of material left as soil cover but did not influence the wheat yield. As is the case with grasslands a multi-species cover crop can promote synergies between ecosystem services, since they can deliver on the production front as well as other ecosystem services such as carbon sequestration and enhanced biodiversity (Accatino et al. 2019). This indicates that there is a possibility that cover crops can enable producers to profitably utilise cover crop material in a conservation agriculture system. Integration of livestock in cropping systems, and specifically conservation agriculture systems, also hold multiple other benefits such as improvement of the economic sustainability, mitigation of climate risk associated with climate change (Bell et al., 2014; Crookes et al., 2017), reduction of weed pressure and reliance on chemicals to control weeds (MacLaren et al. 2019a), and may enhance soil quality and reduce the need for mineral fertilisers (de Andrade Bonetti et al., 2019).

\section{Conclusion}

When cover crops are integrated in a South African rainfed crop rotation system, a cash crop is sacrificed. Utilisation of cover crops can supply additional fodder and has the potential to improve fodder flow in mixed crop-livestock systems. Utilisation of cover crop mixtures in the form of grazing and haymaking decreased mulch load, but soil remained covered after utilisation. Utilised cover crops did not improve or reduce the following season's wheat grain yield, but leguminous cover crops increased wheat grain protein content. Soil quality, in particular nitrogen content was improved through cover cropping and specifically when cover crops were grazed. Therefore, cover crops can be an agronomic tactic to improve system productivity and support sustainable intensification of cropping systems. Load thresholds for cover crops to perform certain functions, or mwultiple functions at once, need to be established for producers to

Page 15/19 
confidently utilise cover crops or crop residue to a certain extent. Use of the term 'cover crop' when utilised for hay or grazing may be confusing to producers, since the cover crop is not only used for covering the soil but also utilised by livestock and could rather be referred to as a 'service crop' when information is disseminated.

\section{Declarations}

\section{Conflict of interest}

The authors declare no conflicts of interest.

\section{Author contributions}

Ernst Smit: Formal analysis, Investigation, Data Curation, Writing - Original Draft; Johann Strauss: Funding acquisition; Writing - Review \& Editing, Supervision, Resources, Data Curation, Conceptualisation; Pieter Swanepoel: Validation, Visualisation, Writing - Review \& Editing, Supervision

\section{Acknowledgements}

The Western Cape Department of Agriculture and Stellenbosch University are acknowledged for funding the project. Dr Stephano Haarhoff is thanked for critically evaluating the manuscript prior to submission.

\section{References}

Accatino, F., Tonda, A., Dross, C., Léger, F., Tichit, M. 2019. Trade-offs and synergies between livestock production and other ecosystem services. Agricultural Systems, 168, 58-72.

Andriarimalala, J.H., Rakotozandriny, J.D.N., Andriamandroso, A.L.H., Penot, E., Naudin, K., Dugué, P., Tillard, E., Decruyenaere, V., Salgado, P., 2013. Creating synergies between conservation agriculture and cattle production in croplivestock farms: a study case in the Lake Alaotra Region of Madagascar. Exp. Agric. 49(3), 352-365.

Agenbag, G.A. 2012. Growth, yield and grain protein content of wheat (Triticum aestivum L.) in response to nitrogen fertiliser rates, crop rotation and soil tillage. S. Afr. J. Plant Soil, 29(2), 73-79.

AgriLASA. 2007. Method No. 6.1.1 for Feeds and Plants. In: P Palic, AS Claasens, J Collier, A Loock, D.H., editor, Agrilasa Handbook of Feeds and Plant Analysis. 2nd ed. Agri Laboratory Association of South Africa, Pretoria

Becker, F., MacLaren, C., Brink, C.J., Jacobs, K., le Roux, M.R., Swanepoel, P.A., 2020. High nitrogen rates do not increase canola yield and may affect soil bacterial functioning. Agron. J., 112(1), 523-536.

Bell, L.W., A.D. Moore, Kirkegaard, J.A., 2014. Evolution in crop-livestock integration systems that improve farm productivity and environmental performance in Australia. Eur. J. Agron. 57: 10-20.

Bell, L.W., Moore, A.D., Thomas, D.T., 2018. Integrating diverse forage sources reduces feed gaps on mixed crop-livestock farms. Animal, 12(9), 1967-1980.

Blanco-Canqui, H., Jasa, P.J., 2019. Do grass and legume cover crops improve soil properties in the long term? SSSA J., 83(4), 1181-1187. 
Blanco-Canqui, H., Shaver, T.M., Lindquist, J.L., Shapiro, C.A., Elmore, R.W., et al., 2015. Cover crops and ecosystem services: Insights from studies in temperate soils. Agron. J. 107(6): 2449-2474.

Crookes, D., Strauss, J.A., Blignaut, J., 2017. The effect of rainfall variability on sustainable wheat production under notill farming systems in the Swartland region, South Africa. African J. Agric. Resour. Econ., 12(1): 62-84.

de Andrade Bonetti, J., Anghinoni, I., Gubiani, P.I., Cecagno, D., de Moraes, M.T., 2019. Impact of a long-term crop-livestock system on the physical and hydraulic properties of an Oxisol. Soil Till. Res., 186, 280-291.

de Faccio Carvalho, P.C., Anghinoni, I., de Moraes, A., de Souza, E.D., Sulc, R.M., et al., 2010. Managing grazing animals to achieve nutrient cycling and soil improvement in no-till integrated systems. Nutr. Cycl. Agroecosyst., 88(2), 259-273.

Fageria, N.K., Baligar, V.C., Bailey., B.A., 2005. Role of cover crops in improving soil and row crop productivity. Commun. Soil Sci. Plant Anal., 36(19-20), 2733-2757.

FERTASA. 2016. Fertilization Handbook. Fertilizer Association of Southern Africa, pp224. FERTASA, Pretoria, South Africa.

Fisher, J., Tozer, P., Abrecht, D., 2012. Livestock in no-till cropping systems - A story of trade-offs. Anim. Prod. Sci., 52(4), 197-214.

Flower, K.C., Cordingley, N. Ward, P.R., Weeks. C., 2012. Nitrogen, weed management and economics with cover crops in conservation agriculture in a Mediterranean climate. Field Crop. Res. 132: 63-75.

Gardner, J.C., Faulkner., D.B., 1991. Use of cover crops with integrated crop-livestock production systems. Integr. Crop. Syst. 11(11): 185-198.

Giller, K.E., Witter, E., Corbeels, M., Tittonell., P., 2009. Conservation agriculture and smallholder farming in Africa: The heretics' view. Field Crop. Res. 114(1): 23-34.

Haarhoff, S.J., Kotzé, T.N., Swanepoel, P.A., 2020. A prospectus for sustainability of rainfed maize production systems in South Africa. Crop Sci., 60(1), 14-28.

Haney, R.L., Haney, E.B., Smith, D.R., Harmel, R.D., White, M.J. 2018. The soil health tool - Theory and initial broad-scale application. Appl. Soil Ecol., 125, 162-168.

MacLaren, C., Storkey, J. Strauss, J.A. Swanepoel, P.A.,Dehnen-Schmutz. K., 2019a. Livestock in diverse cropping systems improve weed management and sustain yields whilst reducing inputs. J. Appl. Ecol., 56, 144-156.

MacLaren, C., Swanepoel, P.A., Bennett, J., Wright, J., Dehnen-Schmutz, K., 2019b. Cover crop biomass production is more important than diversity for weed suppression. Crop Sci., 59(2), 733-748.

MacLaren, C., Labuschagne, J., Swanepoel, P.A., 2021. Tillage practices affect weeds differently in monoculture vs. crop rotation. Soil and Tillage Research, 205, p.104795.

Non-Affiliated Soil Analysis Work Committee, 1990. Handbook of Standard Soil Testing Methods for Advisory Purposes. Soil Science Society of South Africa, Pretoria, South Africa.

Pittelkow, C.M., Linquist, B.A., Lundy, M.E., Liang, X., van Groenigen, K.J., Lee, J., van Gestel, N., Six, J., Ventereae, R.T Kessel, C., 2015. When does no-till yield more? A global meta-analysis. Field Crop. Res., 183, 156-168. 
Ranaivoson, L., K. Naudin, A. Ripoche, F. Affholder, L. Rabeharisoa, Corbeels M., 2017. Agro-ecological functions of crop residues under conservation agriculture. A review. Agron. Sustain. Dev. 37(4) 26.

Rugare, J.T., Pieterse, P.J. and Mabasa, S., 2019. Effect of short-term maize-cover crop rotations on weed emergence, biomass and species composition under conservation agriculture. S. Afr. J. Plant Soil, 36(5), pp.329-337.

Shahbaz, M., Kuzyakov, Y., Sanaullah, M., Heitkamp, F., Zelenev, V., Kumar, A., Blagodatskaya, E., 2017. Microbial decomposition of soil organic matter is mediated by quality and quantity of crop residues: mechanisms and thresholds. Biology Fertil. Soil. 53(3), 287-301.

Shelton, R.E., Jacobsen, K.L. and McCulley, R.L., 2018. Cover crops and fertilization alter nitrogen loss in organic and conventional conservation agriculture systems. Frontiers in Plant Sci., 8, 2260.

Swanepoel, P.A., Agenbag, G.A., Strauss. J.A., 2018. Considering soil quality when comparing disc and tine seed-drill openers for establishing wheat. South Afr. J. Plant Soil: 35(4), 317-320.

Swanepoel, P.A., J. Labuschagne, and M.B. Hardy. 2016. Historical development and future perspective of conservation agriculture practices in crop-pasture rotation systems in the Mediterranean region of South Africa (P. Kyriazopoulos, A., Lopez-Francos, A., Porqueddu, C., Sklavou, Eds.). Ecosyst. Serv. socio-economic benefits Mediterr. grasslands.

Swanepoel, P.A., Le Roux, P.J.G., Agenbag, G.A., Strauss, J.A., MacLaren, C., 2019. Seed-drill opener type and crop residue load affect canola establishment, but only residue load affects yield. Agron. J., 111(4), 1658-1665.

Ward, P.R., Flower, K.C., Cordingley, N. Weeks, C., Micin., S.F., 2012. Soil water balance with cover crops and conservation agriculture in a Mediterranean climate. F. Crop. Res. 132: 33-39.

Zhao, J., Yang, Y., Zhang, K., Jeong, J., Zeng, Z., Zang, H., 2020. Does crop rotation yield more in China? A metaanalysis. Field Crop. Res. 245, 107659.

\section{Figures}

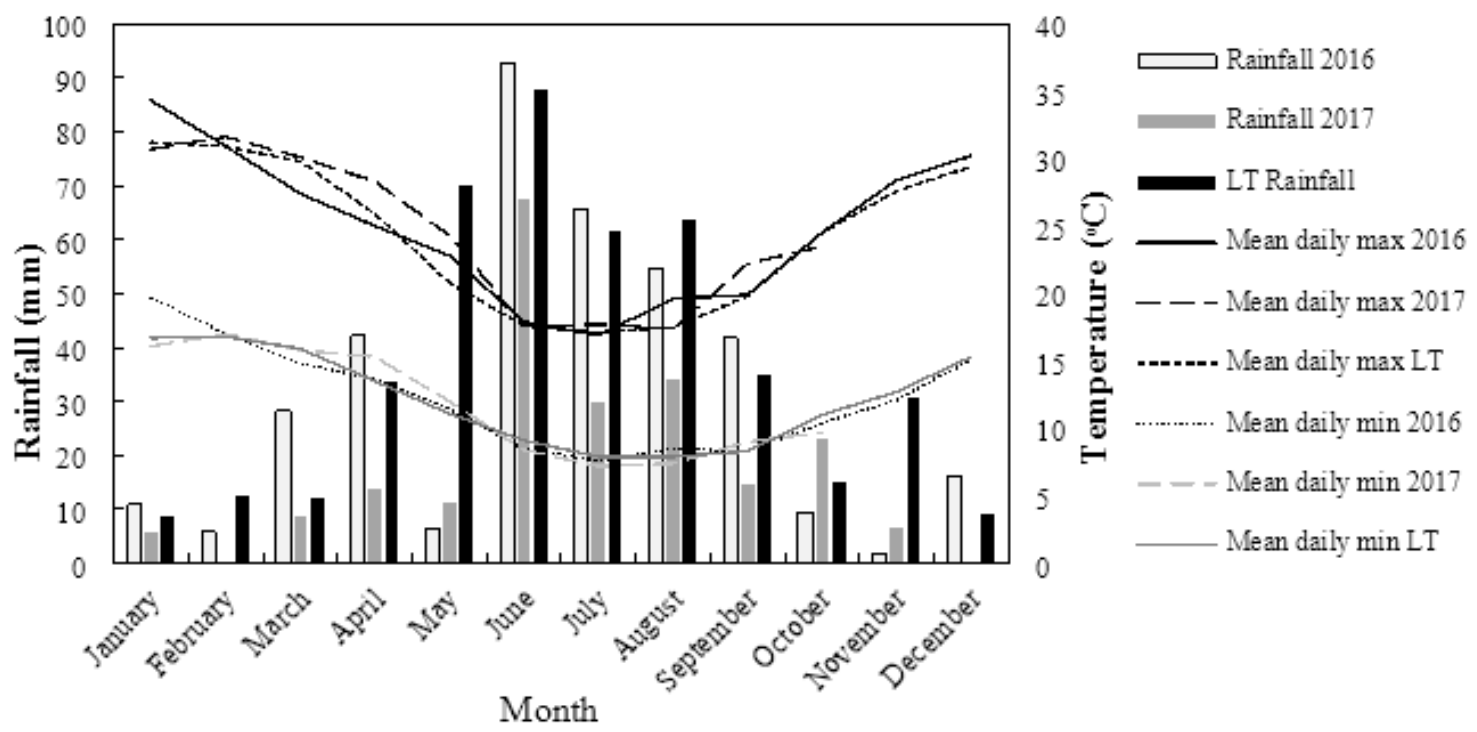

Figure 1 
Long-term (LT) rainfall ( $\mathrm{mm})$, mean minimum and maximum temperatures $\left({ }^{\circ} \mathrm{C}\right)$ of Langgewens Research Farm in the Swartland region of South Africa, as well as rainfall, minimum and maximum temperatures recorded monthly for both 2016 and 2017.

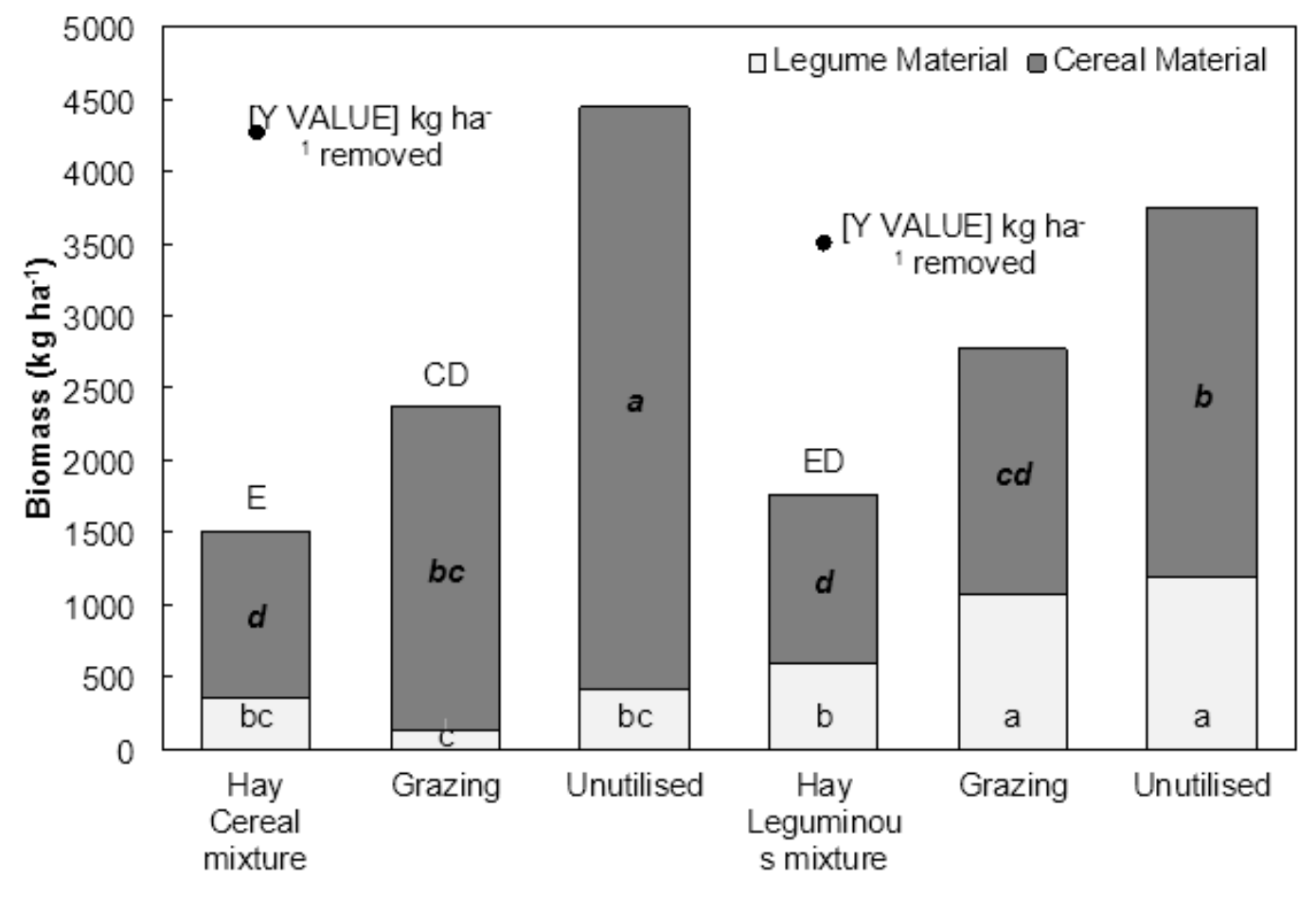

\section{Figure 2}

Total cover crop biomass and the proportions of legume and cereal biomass left on each subplot (hay, grazing and unutilised for the legume- and cereal-based mixtures) after the cover crop growing season. No common uppercase letter above bars indicate a significant difference $(p<0.05)$ in the total amount of cover crop biomass $(S E=252 \mathrm{~kg} \mathrm{ha}-1 ; \mathrm{CV}=$ 48.67). No common lowercase letter within bars indicate a significant difference $(p<0.05)$ in the amount of cereal or leguminous material (cereal: $\mathrm{SE}=263 \mathrm{~kg}$ ha-1; CV = 62.05; leguminous: SE $=130 \mathrm{~kg}$ ha-1; CV =93.26). The amount of material removed as hay is shown by two dots above the hay-bars $(S E=319 \mathrm{~kg}$ ha-1; CV $=29.58 ; \mathrm{P}>0.05)$. 